\title{
REMOVAL OF COBALT(II) FROM AQUEOUS SOLUTION BY LOCAL SAUDI BENTONITE: KINETIC AND EQUILIBRIUM INVESTIGATIONS
}

\author{
Omar K. Alduaij ${ }^{1}$, Mohamed I. Attia ${ }^{1}$, Lotfi Khezami ${ }^{1}$, Kamal K. Taha, ${ }^{1,2,}$ \\ ${ }^{1}$ Department of Chemistry, Science College, \\ Al Imam Mohammad Ibn Saud Islamic University (IMSIU), Riyadh, KSA \\ ${ }^{2}$ Department of Chemistry and Industrial Chemistry, College of Applied \& Industrial Science, \\ University of Bahri, Sudan \\ "kamaltha60@gmail.com
}

\begin{abstract}
Natural bentonite clay from Saudi Arabia was used to remove cobalt from aqueous solution. The clay samples were first characterized for their chemical composition and structure. Batch sorption studies were then conducted to assess their capacity to remove cobalt. The effect of contact time, initial analyte concentration, bentonite dose and temperature on the adsorption was investigated. The results showed that equilibrium was attained in 60 minutes. The metal adsorption was fitted to a Langmuir isotherm model and the maximum monolayer adsorption capacity was found to be $19.85 \mathrm{mg} \mathrm{g}^{-1}$ at $333 \mathrm{~K}$. The pseudosecond-order kinetic model provided the best correlation to the experimental data. The application of an intra-particle diffusion model revealed that the adsorption mechanism of the cobalt ions is a rather complex process and that diffusion is involved in the overall rate of the adsorption process, but it is not the only rate-controlling step. The activation energy, $E_{\mathrm{a}}$, ranged between 4.33 and $9.14 \mathrm{~kJ} \mathrm{~mol}^{-1}$, indicating a physical adsorption process.
\end{abstract}

Keywords: bentonite; cobalt; kinetics; equilibrium

\section{ОТСТРАНУВАњЕ НА КОБАЛТ(ІІ) ОД ВОДНИ РАСТВОРИ СО ЛОКАЛЕН САУДИСКИ БЕНТОНИТ: КИНЕТИЧКИ И РАМНОТЕЖНИ ИСТРАЖУВАЫА}

Природната бентонитна глина од Саудиска Арабија беше употребена за отстранување на кобалт од водни растврори. Глинените примероци прво беа карактеризирани преку хемиска анализа и структура. Потоа беа спроведени сорпциски истражувања со цел да се процени нивниот капацитет за отстранување на кобалт. За атсорпцијата беа испитувани ефектот на времето на дејството, почетната концентрација на аналитот, бентонитната доза и температурата. Резултатите покажаа дека рамнотежата се постигнува за 60 минути. Атсорпцијата на металот беше усогласена со изотермен модел на Langmuir и беше определено дека максималниот монослоен капацитет изнесува 19,85 mg g ${ }^{-1}$ на $333 \mathrm{~K}$. Најдобра корелација беше постигната со кинетички модел од псевдо-втор ред. Примената на дифузиски модел на интра-честички откри дека атсорпцискиот механизам на јоните на кобалт е доста сложен процес и дека вклучува дифузија во севкупната брзина на атсорпцискиот процес, но не е чекорот што ја контролира брзината. Активациската енергија, $E_{\mathrm{a}}$, се движи од 4,33 до $9,14 \mathrm{~kJ} \mathrm{~mol}^{-1}$ што укажува на физички атсорпционен процес.

Клучни зборови: бентонит; кобалт; кинетика; рамнотежа

\section{INTRODUCTION}

Existence of heavy metals in aquatic environments poses a great risk to human health and biota. Thus, elimination of heavy metals is of vital importance to environmental and health organizations. Various processes have been employed for heavy metal removal from effluents and waste- 
water including: chemical coagulation and precipitation [1], reverse osmosis [2], ion exchange [3], adsorption [4], ultrafiltration [5] and others. Of these processes, adsorption is the most effective technique for removing heavy metals [6]. Materials such as activated charcoal [7], clays, natural and synthetic zeolites, kaolinite [8], and rice husks [9] have been used for this purpose. Clays play a significant role in environmental pollution control as natural scavengers of pollutants by eliminating hazardous cations and anions either through adsorption and/or ion exchange.

Clays possess excellent properties such as high cation exchange capacity, availability, low cost, and recycling capability that allow them to be reused for a number of cycles. In particular, bentonite clays are highly efficient in adsorption of heavy metals [11]. Bentonite is a mesoporous, aluminosicicate clay, mainly composed of montmorillonite. Its structure is described as $2: 1$; an inner octahedral sheet is sandwiched between two tetrahedral sheets. Approximately $90-95 \%$ of the total charge in bentonite is negative, thus it acquires a permanent negative charge [10]. Also the zeta potential for bentonite, like many clays, is negative [11]; this is attributed to the high degree of isomorphic substitution of $\mathrm{Al}$ (III) by $\mathrm{Fe}$ (II) or $\mathrm{Mg}(\mathrm{II})$ in the octahedral and some $\mathrm{Si}$ (IV) by $\mathrm{Al}(\mathrm{III})$ in the tetrahedral layers. The negative zeta potential also explains the strong tendency of montmorillonite particles to adsorb cations in order to balance the high negative charge $[12,13]$. A number of researchers have used Saudi bentonite clay for heavy metal removal: Attia et al. [14] succeeded in $100 \%$ removal of $\mathrm{Ni}^{+2}$ from aqueous solutions, while Al-Shahrani [15] reported cobalt removal using bentonite clay.

The adsorption of $\mathrm{Co}$ (II) to bentonite clay displays a strong $\mathrm{pH}$ dependence [15]. At highly acidic $\mathrm{pH}$, the $\mathrm{H}^{+}$or $\mathrm{H}_{3} \mathrm{O}^{+}$ions compete with $\mathrm{Co}(\mathrm{II})$ ions for active binding sites on the surface of bentonite and hence reduce $\mathrm{Co}$ (II) adsorption. At $\mathrm{pH} 3-7$, the adsorption surface becomes less positively charged; hence, electrostatic attraction between $\mathrm{Co}$ (II) ions and the surface of the clay increases resulting in greater removal efficiency. When the $\mathrm{pH}$ is further increased, the formation of a colloidal precipitate of $\mathrm{Co}(\mathrm{OH})_{2}$ commences [16]. Therefore, a $\mathrm{pH}$ value of around 5.5 has been chosen in previous studies to carry out adsorption studies [17].

In this study, the removal of $\mathrm{Co}(\mathrm{II})$ was carried out using natural bentonite clay from Saudi Arabia. The experiments were conducted using solutions at different initial concentrations of $\mathrm{Co}$ (II) and clay doses while the $\mathrm{pH}$ was fixed at
5.5. The equilibrium parameters describing the adsorption process and kinetics, contact time, ion initial concentration and clay dose were obtained.

\section{EXPERIMENTAL}

\subsection{Materials}

The bentonite used in this study was from Kholeis Provenience, Jeddah, KSA. The clay was oven-dried at $105{ }^{\circ} \mathrm{C}$ overnight then screened through a sieve to remove any large solids. The radius of the bentonite adsorbent was determined using an Electronic Microscope JEOL JSM 6510L (Japan) and was found to be $8.15 \times 10^{-4} \mathrm{~mm}$. The XRD analysis was carried out using an X-ray diffractometer (Shimadzu XD-3A) in the diffraction angle range $10^{\circ} \leq 2 \theta \leq 80^{\circ}$, with a monochromatic $\mathrm{CuK}$ radiation $(\lambda=1.5406 \AA)$ source. For chemical analysis, approximately $0.5 \mathrm{~g}$ of bentonite was weighted in a platinum crucible. Then $\mathrm{LiB}_{4} \mathrm{O}_{7}$ was added and the sample was digested at $1000{ }^{\circ} \mathrm{C}$ for one hour. The crucible contents were dissolved in a mixture of $\mathrm{HF}$ and $\mathrm{HCl}$ and heated to $90{ }^{\circ} \mathrm{C}$ while stirring until all the precipitate dissolved. The samples were analyzed for $\mathrm{Na}^{+}, \mathrm{K}^{+}, \mathrm{Mg}^{+2}$, and $\mathrm{Ca}^{+2}$ using a flame photometer (JENWAY PFP7) and for other elements by Inductively Coupled PlasmaAtomic Emission Spectrometry (ICP-ES) (SPECTRO-GENESIS EOP, Germany). The oxides were calculated from the elemental ratios. Phosphorus pentoxide was determined as soluble phosphorus after direct extraction with (EDTA) using ICP-ES [18]. All the chemicals used were of analytical grade and purchased from E. Merck Germany. Characterization of the adsorbent surface was essentially determined from the data of adsorptiondesorption of $\mathrm{N}_{2}$ at $77 \mathrm{~K}$, obtained by using an apparatus ASAP 2020 (Micromeritics). The bentonite sample was introduced in the ASAP 2020 after being outgassed for 2 hours. The mean surface area was classically evaluated from the Brunauer-Emmett-Teller (BET) equation while the volume of micro-pores and the surface area of mesopores were calculated from the $t$-plot method of Lippens and De Boer [19].

\subsection{Preparation of $\mathrm{Co}(\mathrm{II})$ solution}

A stock of cobalt(II) solution (1000 $\mathrm{mg}^{-1}$ ) was prepared by dissolving $\mathrm{CoCl}_{2} \bullet 6 \mathrm{H}_{2} \mathrm{O}$ in distilled water. Solutions of the desired concentration were then obtained by appropriate dilutions. Nitric acid and sodium hydroxide were used to adjust the $\mathrm{pH}$ of solutions accordingly. 


\subsection{Batch experiments}

Adsorption tests were carried out in batch mode by adding different masses of bentonite varying from $0.1-0.8 \mathrm{~g}$ to $250 \mathrm{ml}$ of a $\mathrm{Co}$ (II) solution at a specific concentration and $\mathrm{pH} 5.5$ in an Erlenmeyer flask. A number of flasks were sealed and placed in a thermostated bath and stirred at $500 \mathrm{rpm}$. After a certain contact time, $10 \mathrm{ml}$ of suspension were sampled from each flask and filtered and the residual $\mathrm{Co}$ (II) concentration in the filtrate was measured using ICP-ES. The Co(II) initial concentration ranged between 40 and 240 $\mathrm{mg} \mathrm{l}^{-1}$, while the temperature was set at 25,50 and $60{ }^{\circ} \mathrm{C}$. All experiments were performed in duplicate; however, only the mean values are reported in this paper. The maximum deviation observed was less than $5 \%$.

The amount of adsorbed metal ions was calculated according to Equation 1:

$$
q_{t}=\frac{V\left(C_{0}-C_{t}\right)}{m}
$$

where $q_{t}$ is amount adsorbed (mg metal per g adsorbent), $V$ is the solution volume (l), $C_{0}$ is the initial concentration of metal ions $\left(\mathrm{mg} \mathrm{l}^{-1}\right)$ in solution, $C_{t}$ $\left(\mathrm{mg} \mathrm{l}^{-1}\right)$ is the concentration of metal ion in solution at time $t$ (minutes) and $m$ the mass of bentonite adsorbent $(\mathrm{g})$. The amount adsorbed at equilibrium, $q_{e}$, was calculated using a similar equation (Equation 2) where $C_{e}$ is the liquid-phase concentrations of $\mathrm{Co}(\mathrm{II})$ after equilibrium is reached:

$$
q_{e}=\frac{V\left(C_{0}-C_{e}\right)}{m} .
$$

The adsorption efficiency $(\% S)$ of metal ions on bentonite was calculated by Equation 3:

$$
\% S=\frac{\left(C_{0}-C_{e}\right)}{C_{0}} \times 100 .
$$

In order to characterize the bentonite adsorbent for its adsorption efficiency, the adsorption capacity was also calculated from the adsorption isotherms. The cobalt sorption data were fitted with the theoretical models of the Langmuir isotherm in its linear form:

$$
\frac{C_{e}}{q_{e}}=\frac{1}{Q_{0}} C_{e}+\frac{1}{Q_{0} b},
$$

where $Q_{0}$ is the adsorbent concentration corresponding to the complete coverage of adsorption sites, and $b$ is a constant related to the free energy of adsorption.

\subsection{Kinetic study}

Pseudo-first-order, pseudo-second-order and intraparticle diffusion equations were considered for interpreting the experimental kinetics data. The pseudo-first-order rate expression [20] and the pseudo-second-order rate expression [21] are given in Equation 5 and Equation 6, respectively:

$$
\begin{aligned}
& \frac{1}{q_{t}}=\frac{k_{1}}{q_{e}} \frac{1}{t}+\frac{1}{q_{e}} \\
& \frac{t}{q_{t}}=\frac{1}{k_{2} q_{e}^{2}}+\frac{1}{q_{e}} t
\end{aligned}
$$

where $q_{e}$ and $q_{t}$ are the amounts $\left(\mathrm{mol} \mathrm{g}^{-1}\right)$ of metal ion adsorbed on adsorbent at equilibrium and at various times $t$, respectively; $k_{l}$ is the rate constant of the first-order model for the adsorption process $\left(\mathrm{min}^{-1}\right)$; and $k_{2}$ is the rate constant of the pseudosecond-order model of the adsorption process ( $\mathrm{g}$ $\mathrm{mol}^{-1} \mathrm{~min}^{-1}$ ). The half-adsorption time, $t_{1 / 2}$, characterizes the adsorption rate well and is the time required to uptake half of the maximal amount of metal ion adsorbed at equilibrium; in the case of a pseudo-second-order process, its value is given by Equation 7 [22]:

$$
t_{1 / 2}=\frac{1}{k_{2} q_{e}} .
$$

The intraparticle diffusion model is characterized by a linear relationship between the amount adsorbed at time $t\left(q_{t}\right)$ and the square root of the time, and is expressed by Equation 8 [23]:

$$
q_{t}=k_{i d} t^{1 / 2}+C
$$

where $q_{t}$ is the amount of metal ion adsorbed at time $t$ (min) expressed in $\mathrm{mg} \mathrm{g}^{-1}, k_{i d}$ is the initial rate constant $\left(\mathrm{mg} \mathrm{g}^{-1} \mathrm{~min}^{-1 / 2}\right.$ ) of intraparticle diffusion, $t$ is the time of sorption duration ( $\mathrm{min}$ ), and $C$ gives information about the boundary layer thickness.

The mass diffusivity that depends mainly on the surface properties of the adsorbent can be calculated according to Equation 9, as suggested by Yadava et al. [24]:

$$
t_{1 / 2}=\frac{0.03 r_{0}^{2}}{D}
$$

where $D$ is the mass diffusivity $\left(\mathrm{cm}^{2} \mathrm{~s}^{-1}\right)$ and $r_{0}$ is the spherical-equivalent radius of the adsorbent particle $(\mathrm{cm})$. 
The activation energy is usually calculated from the linear form of the Arrhenius equation (Equation 10):

$$
\ln k=\ln k_{0}-\frac{E_{a}}{R T},
$$

where $k_{0}$ is the pre-exponential factor and $E_{\mathrm{a}}$ the activation energy of sorption $\left(\mathrm{kJ} \mathrm{mol}^{-1}\right)$. After plotting $\ln (k)$ as a function of $T^{-1}$, the values of activation energy are determined from the slope of the regression line.

\section{RESULTS AND DISCUSSION}

\section{1. $X R D$}

The diffractograms of bentonite (Fig. 1) shows the presence of the characteristic peaks of montmorillonite $\left(2 \theta=22^{\circ}\right.$ and $\left.62^{\circ}\right)$ and quartz $\left(2 \theta=27^{\circ}\right)[25]$ as the main components of Saudi bentonite [26].

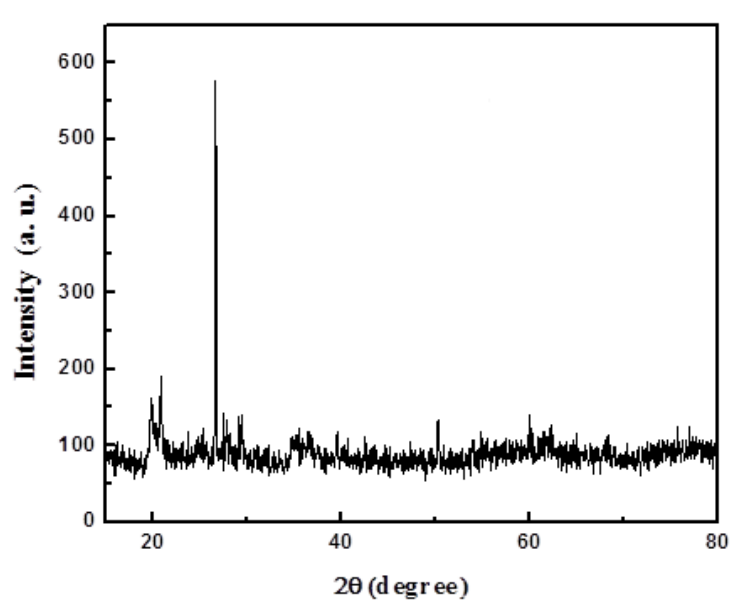

Fig. 1. XRD spectrum of Saudi bentonite

\subsection{Elemental content}

The composition of the bentonite determined with ICP-ES was: $\mathrm{SiO}_{2}(57.27 \%), \mathrm{CaO}(3.54 \%)$, $\mathrm{MgO}(1.54 \%), \mathrm{Na}_{2} \mathrm{O}(1.02 \%), \mathrm{K}_{2} \mathrm{O}(0.42 \%)$, $\mathrm{Al}_{2} \mathrm{O}_{3}(18.39 \%), \mathrm{SO}^{2-}{ }_{4}(7.65 \%), \mathrm{Cl}^{-}(0.15 \%)$, $\mathrm{P}_{2} \mathrm{O}_{5}(0.25 \%), \mathrm{Fe}(1.98 \%), \mathrm{Cu}(0.02 \mathrm{ppm}), \mathrm{Cr}$ (0.01 ppm), Zn (10.01 ppm) and Mn (7.30 ppm). The values reported here are similar to a previous data of Saudi bentonite [26].

\section{3. $N_{2}$ adsorption/desorption isotherms}

Figure 2 depicts the nitrogen adsorptiondesorption isotherm of the bentonite. The isotherm can be assigned as Type II, indicating non-porous or macroporous particles [8]. The hysteresis loops occurring at $\mathrm{p} / \mathrm{p}_{0}>0.5$ (not inside the typical
Brunauer-Emmett-Teller (BET) range) is of Type $\mathrm{H} 3$ in the IUPAC classification [8]. A hysteresis loop of this type indicates either slit-shaped pores or assemblages of platy particles of montmorillonite [19]. The pore size distribution (Fig. 3) shows a pore diameter in the $20-50 \mathrm{~nm}$ range, thus supporting the mesoporous nature of the bentonite.

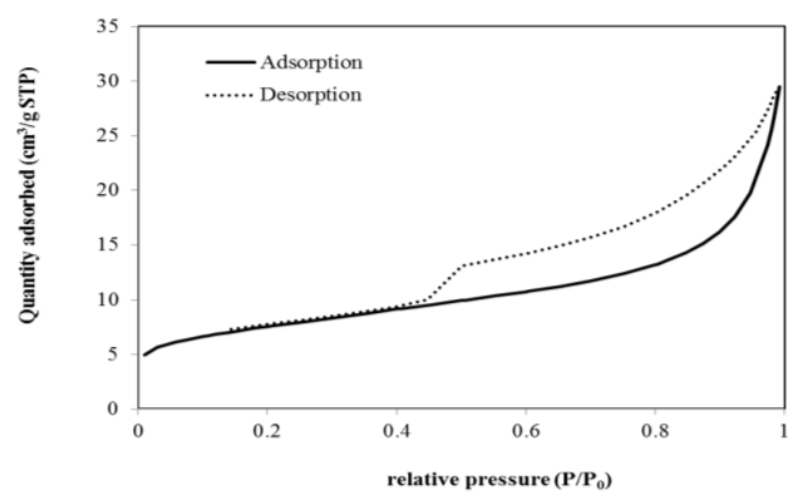

Fig. 2. Adsorption-desorption isotherms of $\mathrm{N}_{2}$ on Saudi Arabia bentonite powder at $77 \mathrm{~K}$

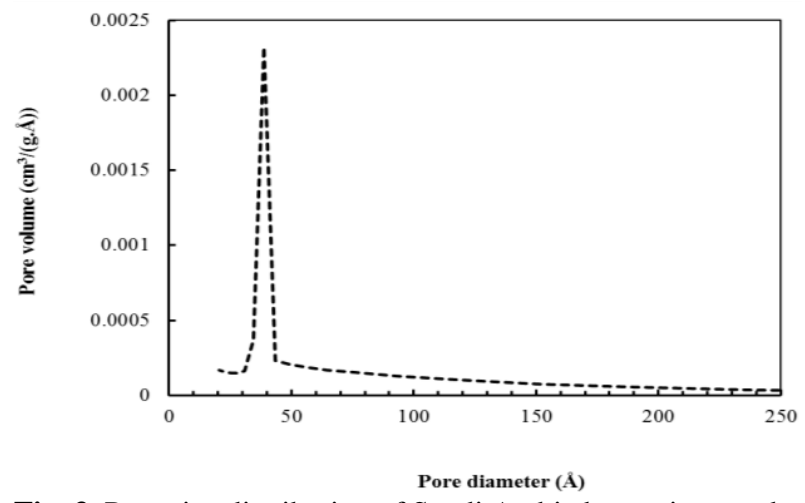

Fig. 3. Pore size distribution of Saudi Arabia bentonite powder

The bentonite adsorbent has a surface area of $\approx 27 \mathrm{~m}^{2} \mathrm{~g}^{-1}$ and a pore diameter and volume of $90.83 \AA$ and $0.043 \mathrm{~cm}^{3} \mathrm{~g}^{-1}$, respectively. A surface area of $34.1 \mathrm{~m}^{2} \mathrm{~g}^{-1}$ was reported for natural Brazilian bentonite [25], $20 \mathrm{~m}^{2} \mathrm{~g}^{-1}$ for bentonite from China [27] and $31.67 \mathrm{~m}^{2} \mathrm{~g}^{-1}$ for Turkish bentonite [28]. A pore volume and pore diameter of 0.06075 $\mathrm{cm}^{3} \mathrm{~g}^{-1}$ and $76.72 \AA$, respectively, have been previously reported for bentonite clays [25]. Specific surface areas of 23.9 and $18.6 \mathrm{~m}^{2} \mathrm{~g}^{-1}$ for untreated montmorillonite were reported by Bourg et al. [29] and Goldberg [30], respectively. Such small values of surface area were attributed to the limited penetration of $\mathrm{N}_{2}$ gas molecules through the interlayer regions between the layer sheets [31].

\subsection{Effect of contact time}

Figure 4 shows the effect of contact time on the adsorption of $\mathrm{Co}$ (II) onto Saudi bentonite for different initial $\mathrm{Co}(\mathrm{II})$ concentrations. 



Fig. 4. Variation of Co(II) removal with time and concentration at different temperatures

The contact time was varied from 0 to 250 minutes to investigate the optimum contact time between the adsorbate and adsorbent. The initial concentration of cobalt ranged from 40 to $240 \mathrm{mg}$ $\mathrm{l}^{-1}$ with a fixed $0.20 \mathrm{~g}$ per $50 \mathrm{ml}$ dose of bentonite. The $\mathrm{pH}$ of the solution was kept constant at 5.5 and measurements were made at 25,50 and $60{ }^{\circ} \mathrm{C}$. Equilibrium for the adsorption of cobalt ions onto the bentonite was attained after 60 minutes with initial concentrations of $240 \mathrm{mg} \mathrm{l}^{-1}$ at $60{ }^{\circ} \mathrm{C}$. Thus an equilibrium was attained is shorter time interval in comparison to the equilibrium time of 150 [32] and 120 minutes [33] reported for cadmium removal.

\subsection{Effect of initial concentration}

The effect of the initial Co(II) concentrations on the Co(II) removal was investigated as shown in Figure 4. At $40 \mathrm{mg} \mathrm{l}^{-1}$, the removal efficiency was about $70 \%$, whereas it dropped to about $30 \%$ when the $\mathrm{Co}$ (II) concentration was increased to $240 \mathrm{mg} \mathrm{l}^{-1}$. This may be attributed to the saturation of bentonite adsorption sites with the metal ions. A similar trend was reported by AlShahrani [15], where $90 \%$ cobalt removal was observed when the initial concentration was $25 \mathrm{mg}$ $1^{-1}$ and a prominent decrease to $37 \%$ was observed when the concentration was increased to $200 \mathrm{mg} \mathrm{l}^{-1}$.

\subsection{Co(II) adsorption isotherm}

The values of Langmuir constants $b$ and $Q_{0}$ tabulated in Table 1, were calculated from the slope and intercept, respectively, of the linear plot of $C_{\mathrm{e}} \mathrm{q}^{-1}$ vs. $C_{\mathrm{e}}$ displayed in Figure 5 .
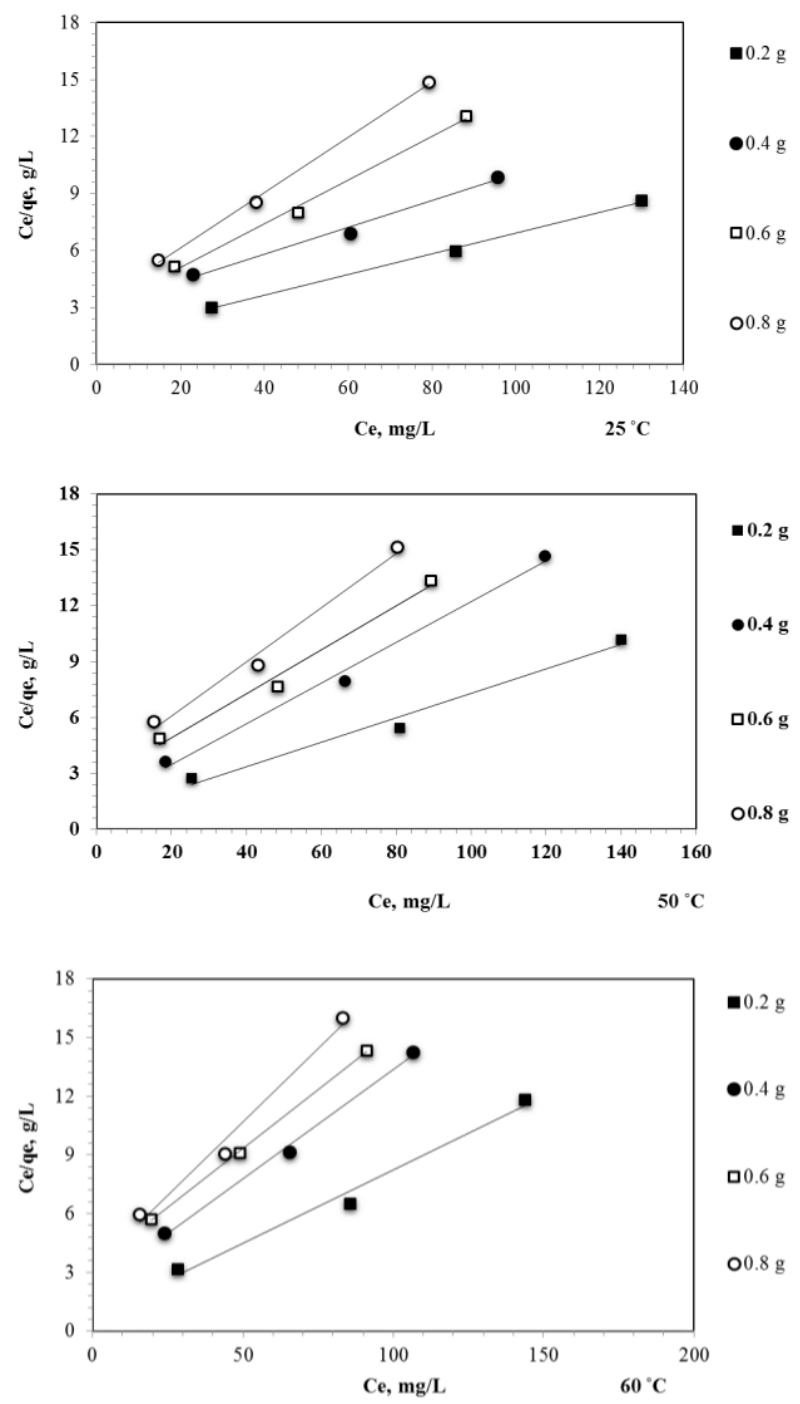

Fig. 5. Langmuir equilibrium adsorption linear isotherms for $\mathrm{Co}(\mathrm{II})$ onto different doses of bentonite at different temperatures and $\mathrm{pH}=5.5$ 
The coefficient $b$ is related to the binding energy and $Q_{0}$ is the maximum adsorption capacity determined by the number of reactive surface sites in an ideal monolayer system.

The maximum value obtained for $Q_{0}$ is $19.85 \mathrm{mg} \mathrm{g}^{-1}$, which is higher than the $7.30 \mathrm{mg} \mathrm{g}^{-1}$ obtained by Al-Shahrani [15] for cobalt adsorption onto Saudi bentonite. This difference may have resulted from the short equilibrium time (30 minutes) compared to the longer time (60 minutes) reported here.

The essential features of the Langmuir isotherm may be expressed in terms of the equilibrium parameter (i.e. separation factor), $R_{\mathrm{L}}$, which is a dimensionless constant described by Equation 11 $[34,35]$ :

$$
R_{L}=\frac{1}{1+b C_{0}}
$$

The $R_{\mathrm{L}}$ value indicates if the adsorption is irreversible $\left(R_{\mathrm{L}}=0\right)$, favorable if $0<R_{\mathrm{L}}<1$, linear if $R_{\mathrm{L}}=1$ and unfavourable if $R_{\mathrm{L}}>1$.

\section{Table 1}

Effect of temperature and bentonite dose on the values of Langmuir isotherm constants for Co(II) adsorption at $\mathrm{pH}=5.5$

\begin{tabular}{cccccc}
\hline $\begin{array}{c}\text { Bentonite } \\
\text { dose }(\mathrm{g})\end{array}$ & $\begin{array}{c}T \\
(\mathrm{~K})\end{array}$ & $\begin{array}{c}\boldsymbol{Q}_{\boldsymbol{0}} \\
\left(\mathrm{mg} \mathrm{g}^{-1}\right)\end{array}$ & $\begin{array}{c}\boldsymbol{b} \\
\left(\mathrm{l} \mathrm{mg}^{-1}\right)\end{array}$ & $\boldsymbol{r}^{2}$ & $\boldsymbol{R}_{\boldsymbol{L}}$ \\
\hline \multirow{2}{*}{0.2} & 298 & 15.29 & 0.0878 & 0.9811 & 0.0448 \\
& 323 & 18.25 & 0.0379 & 0.9978 & \\
& 333 & 19.85 & 0.0288 & 0.9852 & \\
0.4 & 298 & 9.12 & 0.0864 & 0.9911 & 0.0455 \\
& 323 & 14.16 & 0.0237 & 0.9883 & \\
\multirow{2}{*}{0.6} & 333 & 15.38 & 0.0187 & 0.9957 & \\
& 298 & 8.28 & 0.0463 & 0.9853 & 0.0817 \\
& 323 & 9.02 & 0.0337 & 0.9954 & \\
\multirow{2}{*}{0.8} & 333 & 9.32 & 0.0288 & 0.9995 & \\
& 298 & 6.87 & 0.0458 & 0.9857 & 0.0825 \\
& 323 & 6.86 & 0.0399 & 0.9980 & \\
\hline
\end{tabular}

From the Langmuir isotherms fitting parameters (Table 2), the maximum monolayer coverage capacity $\left(Q_{o}\right)$ was found to be $19.85 \mathrm{mg} \mathrm{g}^{-1}, b$ (Langmuir isotherm constant) was $0.0487 \mathrm{l} / \mathrm{mg}, R_{\mathrm{L}}$ (the separation factor) is 0.0825 indicating that the equilibrium sorption was favourable and the $R^{2}$ value was $\approx 0.99$ proving that the adsorption data fitted well to Langmuir isotherm model.

Angove et al. [36] studied the influence of temperature ( 283 to $343 \mathrm{~K}$ ) on adsorption of $\mathrm{Co}$ (II) on kaolinite and reported that the experimental data fit the Langmuir model at all temperatures. Many other authors reported results supporting the assumption that a Langmuir monolayer adsorption isotherm describes heavy metal adsorption on clay $[37,38]$.

\subsection{Effect of bentonite dosage}

Adsorption of $\mathrm{Co}(\mathrm{II})$ ions on bentonite was studied at different adsorbent doses [0.2, 0.4, 0.6 and $0.8 \mathrm{~g}$ per $50 \mathrm{ml}$ ] at initial an cobalt concentration of $240 \mathrm{mg} \mathrm{l}^{-1}$, with temperatures of 298,323 and $333 \mathrm{~K}$ and a contact time of 4.0 hours. The data in Figure 5 and Table 1 show that with the increase of adsorbent dose, the adsorption (adsorbed amount,) decreased; the maximum Co(II) removal was observed with adsorbent dose of $0.2 \mathrm{~g}$ per $50 \mathrm{ml}$. This trend may result from the aggregation of adsorbent particles [39] at higher doses. Also when bentonite interacts with water it forms a gel-like, sticky material that makes the use of large concentrations not preferable for adsorption [40]. Increasing the temperature for all the bentonite doses leads to an observable improvement in adsorption capacity, suggesting an endothermic nature of the adsorption process [22].

\subsection{Kinetic study}

Pseudo-first-order and pseudo-second-order kinetics models at 25,50 and $60{ }^{\circ} \mathrm{C}$ are displayed in Figures $6 \mathrm{a}-\mathrm{b}$ and the interpreted data is tabulated in Table 2. From the table it can be seen that the corresponding correlation coefficients $\left(r^{2}\right)$ are close to unity, indicating that the experimental data fits the pseudo-second-order model equation [41]. This finding suggests that the adsorption process includes two steps, i.e. an initial rapid adsorption followed by a much slower step. The rapid adsorption process may be attributed to the existence of large numbers of adsorption sites on the external surface of bentonite sample [42]. The subsequent slow adsorption procedure is assigned to the exchange with ions on the outer surface of bentonite material or the longer diffusion path of the metal ion into the inner pores of bentonite. Such a longer diffusion path could obviously cause slow adsorption at the later stages. The agreement between the experimental and calculated $q_{e}$ (Equation 6) values further supports the pseudo-second-order kinetics model [43]. The experimental values of $q_{\mathrm{e}}$ for the pseudo-first-order model do not agree with the theoretical values calculated from Equation 5; hence, the pseudo-first-order model is not suitable for modeling the adsorption of $\mathrm{Co}$ (II) onto bentonite. 

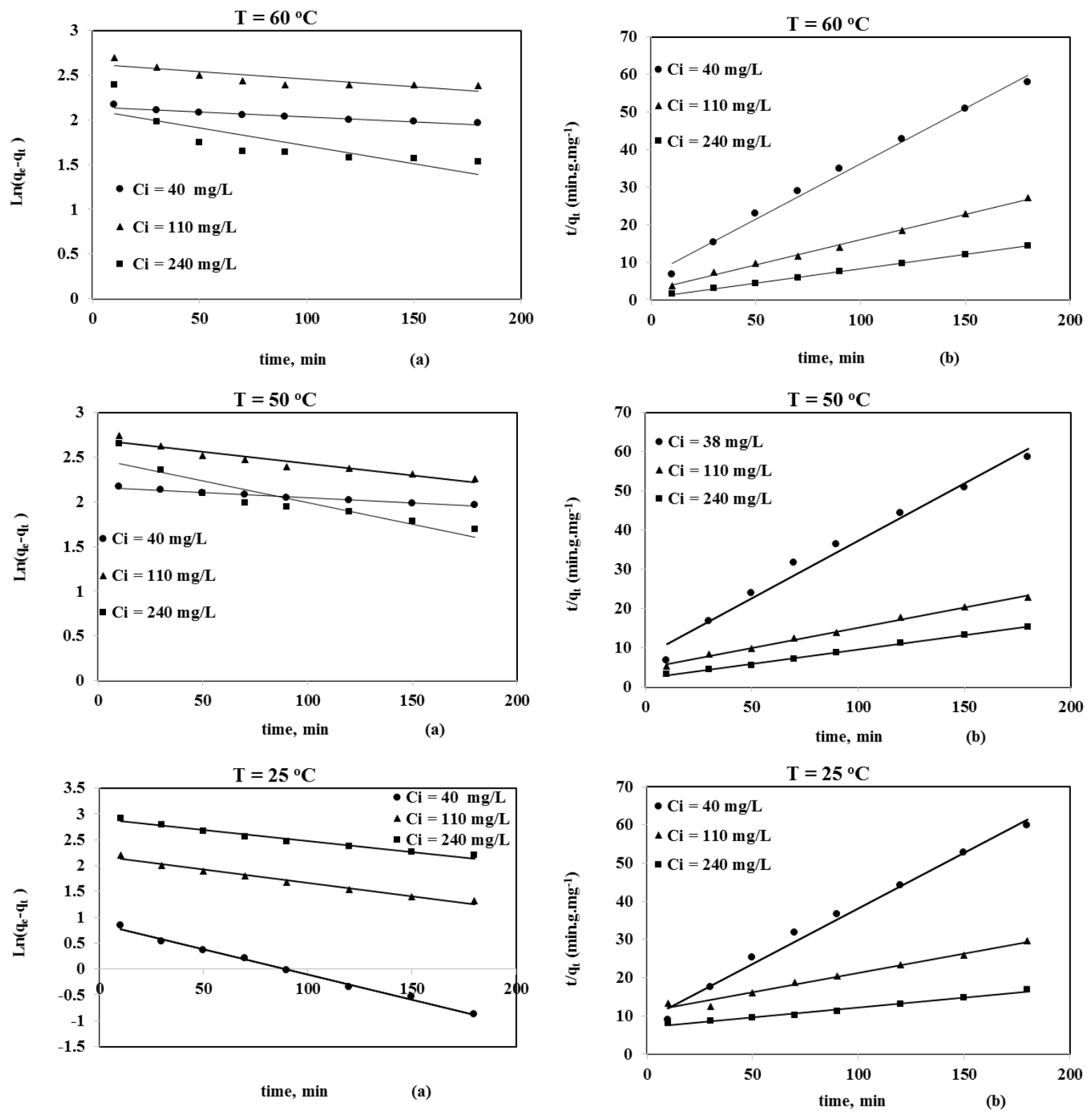

Fig. 6. (a) First order and (b) second-order kinetic equation for adsorption of Co(II) on bentonite at different temperatures and $\mathrm{pH}=5.5$

Table 2

Rate adsorption constants for the pseudo-first-order and pseudo-second-order kinetic models at different temperatures

\begin{tabular}{|c|c|c|c|c|c|c|c|c|c|c|}
\hline \multirow[b]{2}{*}{$\begin{array}{l}\mathbf{T} \\
(\mathrm{K})\end{array}$} & \multirow{2}{*}{$\begin{array}{l}\text { Initial con- } \\
\text { centration } \\
\left(\mathrm{mg} \cdot \mathrm{l}^{-1}\right)\end{array}$} & \multirow[b]{2}{*}{$\begin{array}{c}\boldsymbol{q}_{e(\exp )}{ }^{a} \\
\left(\mathrm{mg} \cdot \mathrm{g}^{-1}\right)\end{array}$} & \multicolumn{3}{|c|}{ First-order } & \multicolumn{5}{|c|}{ Second-order } \\
\hline & & & $\begin{array}{r}\boldsymbol{K}_{1} \times 10^{3} \\
\left(\min ^{-1}\right)\end{array}$ & $\begin{array}{c}\boldsymbol{q}_{\boldsymbol{e}(\mathrm{cal})}{ }^{b} \\
\left(\mathrm{mg} \cdot \mathrm{g}^{-1}\right)\end{array}$ & $r^{2}$ & $\begin{array}{c}\boldsymbol{k}_{2} \times 10^{3} \\
\left(\mathrm{~g} \cdot \mathrm{mg}^{-1} \cdot \mathrm{min}^{-1}\right)\end{array}$ & $\begin{array}{c}\boldsymbol{q}_{\boldsymbol{e}(\mathrm{cal})}{ }^{b} \\
\left(\mathrm{mg} \cdot \mathrm{g}^{-1}\right)\end{array}$ & $\begin{array}{c}\boldsymbol{t}_{1 / 2} \\
(\mathrm{~min})\end{array}$ & $\begin{array}{l}\boldsymbol{D} \times 10^{13} \\
\left(\mathrm{~cm}^{2} \cdot \mathrm{s}^{-1}\right)\end{array}$ & $r^{2}$ \\
\hline \multirow{3}{*}{298} & 40 & 3.05 & 9.7 & 2.38 & 0.9949 & 9.38 & 3.43 & 31.08 & 1.07 & 0.9894 \\
\hline & 110 & 9.25 & 5.1 & 8.81 & 0.98 & 0.93 & 9.85 & 109.16 & 0.304 & 0.9886 \\
\hline & 240 & 20.06 & 4.3 & 18.24 & 0.9749 & 0.36 & 19.76 & 140.58 & 0.236 & 0.9803 \\
\hline \multirow{3}{*}{323} & 40 & 3.10 & 1.2 & 8.7 & 0.9768 & 10.7 & 3.42 & 27.33 & 1.22 & 0.9818 \\
\hline & 110 & 9.87 & 2.6 & 14.78 & 0.9162 & 3.06 & 9.44 & 34.62 & 0.959 & 0.9951 \\
\hline & 240 & 14.32 & 4.4 & 11.68 & 0.8809 & 2.35 & 13.7 & 31.06 & 1.07 & 0.9961 \\
\hline \multirow{3}{*}{333} & 40 & 3.16 & 1.2 & 8.81 & 0.9826 & 10.6 & 3.54 & 26.65 & 1.25 & 0.9818 \\
\hline & 110 & 6.91 & 1.6 & 13.6 & 0.6701 & 8.02 & 7.29 & 17.1 & 1.94 & 0.9939 \\
\hline & 240 & 12.63 & 3.6 & 8.03 & 0.5679 & 9.89 & 12.97 & 7.8 & 4.26 & 0.9971 \\
\hline
\end{tabular}

${ }^{\mathrm{a}}$ : experimental data, ${ }^{\mathrm{b}}$ : calculated data from models 
A similar result was reported by Liu and Zhou [44] who found that the kinetic adsorption on bentonite could be fitted with pseudo-second order kinetics. Bhattacharyya and Gupta [45] investigated Lagergren first order kinetics, second order kinetics using the Elovich equation, intra-particle diffusion mechanism, and liquid film diffusion model for Co(II)-clay interactions and concluded that the second order kinetics best fit their experimental data. The half-adsorption time $\left(t_{1 / 2}\right)$ values decrease as the temperature increases for each initial concentration. For instance, the $t_{1 / 2}$ values for an initial Co(II) concentration of $40 \mathrm{mg} \mathrm{l}^{-1}$ were $31.08,27.33$ and 26.65 minutes for 298,323 and $333 \mathrm{~K}$, respectively (Table 2).

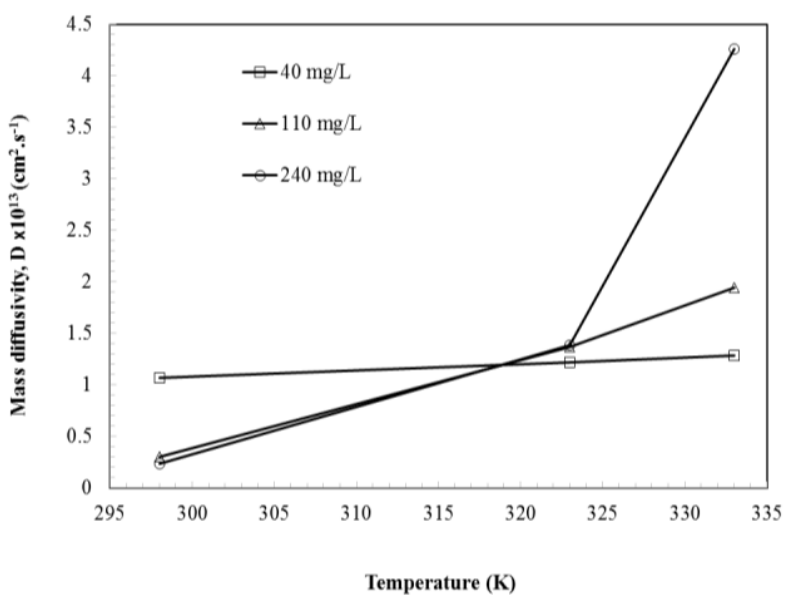

Fig.7. Variation of mass diffusivity with temperature for different initial concentrations of $\mathrm{Co}$ (II) determined using an intraparticle diffusion model

Figure 7 shows the change of mass diffusivity with temperature for different concentrations of Co(II). The $r_{0}$ value was $8.15 \times 10^{-4} \mathrm{~mm}$ as obtained from the Electronic Microscope measurement. The mass diffusivity has increased from $10^{-11}$ to $10^{-13} \mathrm{~cm}^{2} \mathrm{~s}^{-1}$ as the temperature was raised from 298 to $333 \mathrm{~K}$. A similar trend and a value of $10^{-9} \mathrm{~cm}^{2} \mathrm{~s}$ was reported for $\mathrm{Cr}(\mathrm{VI})$ on activated carbon [22].

In Figure 8, the plot of $q_{\mathrm{t}}$ vs. $t^{1 / 2}$ is linear with $r^{2}=0.99$ as seen in Table 3 , indicating that the intraparticle diffusion is involved in the adsorption process. The nonzero intercept is a clear indication that some other mechanism along with intraparticle diffusion is also involved with the intraparticle diffusion. In other words the intraparticle diffusion is not the only rate-controlling step in the $\mathrm{Co}$ (II) ion diffusion [46, 47]. Milosavljević et al. [48] reported that if the data represent multi-linearity, then two or more steps influence the adsorption process. The $C$ values are very small, making the lines pass very close to the origin, indicating a narrow boundary layer thickness, i.e. less resistance to external mass transfer [22]. The values of $C$ increased as the temperature was increased, indicating a larger effect of intraparticle diffusion at higher temperatures.



Fig. 8. Intraparticle diffusion plots for adsorption of Co(II) on natural clay at different temperatures and $\mathrm{pH} 5.5 ; C_{0}=40 \mathrm{mg} \mathrm{l}^{-1}$.

Table 3

Intra-particular diffusion model parameters

\begin{tabular}{cccc}
\hline \hline$T(\mathrm{~K})$ & $K_{i d}\left(\mathrm{mg} \mathrm{g}^{-1} \mathrm{~min}^{-1 / 2}\right)$ & $C\left(\mathrm{mg} \mathrm{g}^{-1}\right)$ & $r^{2}$ \\
\hline 298 & 0.1818 & 0.6665 & 0.9862 \\
323 & 0.1614 & 0.9327 & 0.996 \\
333 & 0.1549 & 1.0853 & 0.9927 \\
\hline \hline
\end{tabular}

Arrhenius equation (Equation 10) was used to construct the graph (Figure 9) to calculate the energy of activation of $\mathrm{Co}$ (II) adsorption onto bentonite, taking the $k_{2}$ from the pseudo-second-order kinetics. The $E_{\mathrm{a}}$ values were $4.433,6.756$ and $9.142 \mathrm{~kJ} \mathrm{~mol}^{-1}$, indicating a physisorption process (Table 4).

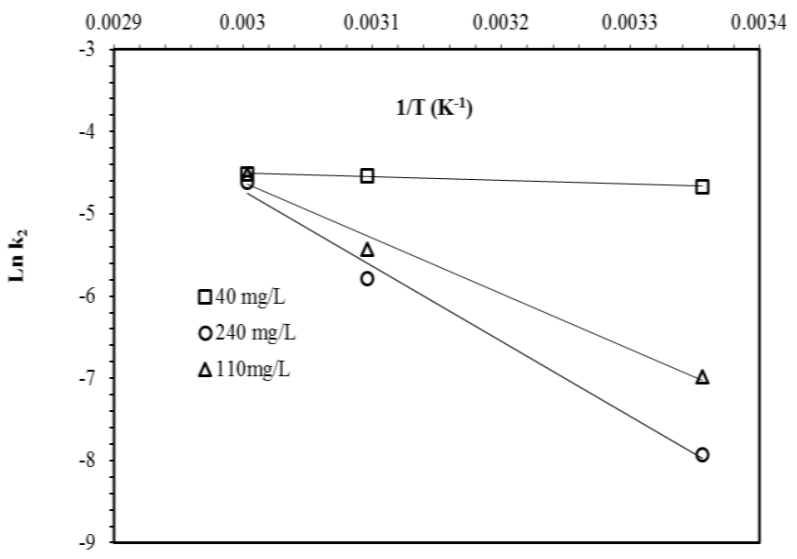

Fig. 9. Arrhenius plot for adsorption of $\mathrm{Co}(\mathrm{II})$ onto natural clay for different initial concentrations at $\mathrm{pH} 5.5$ 
T a ble 4

\section{Activation energy for Co (II) adsorption}

\begin{tabular}{cccc}
\hline \hline $\begin{array}{c}\text { Co(II) initial concentration } \\
\left(\mathrm{mg} \mathrm{l}^{-1}\right)\end{array}$ & $\begin{array}{c}E a \\
\left(\mathrm{~J} \mathrm{~mol}^{-1}\right)\end{array}$ & $\ln K_{0}$ & $r^{2}$ \\
\hline 40 & 4433.0 & -3.178 & 0.9795 \\
110 & 6756.0 & 15.647 & 0.9857 \\
240 & 9141.7 & 22.698 & 0.9899 \\
\hline \hline
\end{tabular}

\section{CONCLUSIONS}

A Saudi indigenous bentonite has been identified as an effective adsorbent to remove $\mathrm{Co}(\mathrm{II})$ ions from aqueous solutions. The bentonite was characterized via XRD and $\mathrm{N}_{2}$ adsorption before its chemical composition was analyzed. Batch adsorption of the ions under study was carried out. The second-order kinetic model was typically found to mimic the kinetic data. Moreover, the equilibrium data of adsorption was in agreement with Langmuir's model under all operating parameters: temperature, initial $\mathrm{Co}$ (II) concentrations and adsorbent dose. The adsorption capacities of the bentonite for $\mathrm{Co}$ (II) reported here, was higher than previous data for bentonite samples from Saudi Arabia [15]. Increasing the temperature not only enhanced the rate of adsorption, but also its extent; this finding was supported by the positive value for the enthalpy change of the adsorption reaction.

Acknowledgement. The authors would like to thank the National Plan, for Sciences, Technology and Innovation, (MAARIFAH), King Abdulaziz City for Sciences \& Technology, Kingdom of Saudi Arabia.

\section{REFERENCES}

[1] L. Charerntanyarak. Heavy metals removal by chemical coagulation and precipitation. Water Science and Technology, 39(10-11):135-138 (1999).

[2] M. Mohsen-Nia, P. Montazeri, H. Modarress. Removal of $\mathrm{Cu}^{2+}$ and $\mathrm{Ni}^{2+}$ from waste water with a chelating agent and reverse osmosis processes. Desalination, 217(1-3):276-281 (2007).

[3] S. Y. Kang, JU Lee, S. H. Moon, K. W. Kim. Competitive adsorption characteristics of $\mathrm{Co}^{2+}, \mathrm{Ni}^{2+}$, and $\mathrm{Cr}^{3+}$ by IRN-77 cation exchange resin in synthesized, wastewater. Chemosphere, 56(2):141-147 (2004).

[4] M. Q. Jiang, X. Y. Jin, X. Lu and Z. L. Chen. Adsorption of $\mathrm{Pb}$ (II), $\mathrm{Cd}(\mathrm{II}), \mathrm{Ni}$ (II) and $\mathrm{Cu}$ (II) onto natural kaolinite clay. Desalination, 252; 33-39 (2010).

[5] J. Landáburu-Aguirre, V. García, E. Pongrácz, R. L. Keiski. The removal of zinc from synthetic wastewaters by micellar-enhanced ultrafiltration: statistical design of experiments. Desalination, 240(1-3); 262-269 (2009).

[6] K. D. Adebowale, E. I. Emmanuel, B. I. Dlu-Dwolabi. Kinetic and thermodynamic aspects of the adsorption of $\mathrm{Pb}^{2+}$ and $\mathrm{Cd}^{2+}$ ions on tripolyphosphate-modified kaolin- ite clay. Chemical Engineering Journal, 136 (2-3); 99 107 (2008).

[7] S. Yao, J. Zhang, D. Shen, R. Xiao, S. Gu, M. Zhao, J. Liang. Removal of $\mathrm{Pb}$ (II) from water by the activated carbon modified by nitric acid under microwave heating, Journal of Colloid and Interface Science, 463; 118-127 (2016).

[8] J. Rouquerol, F. Rouquerol, P. Llewellyn, G. Maurin and S. K. W. Sing, Adsorption by Powders and Porous Solids (Second edition), Principles, Methodology and Applications, Academic Press, San Diego, 2013.

[9] V. G. Georgieva, M. P. Tavlieva, S. D. Genieva and L. T. Vlaev, Adsorption kinetics of $\mathrm{Cr}(\mathrm{VI})$ ions from aqueous solutions onto black rice husk ash, Journal of Molecular Liquids, 208; 219-226 (2015).

[10] M. Duc, F. Gaboriaud, F. Thomas, Sensitivity of the acid-base properties of clays to the methods of preparation and measurement. 1. Literature review, J. Colloid Interface Sci. 289; 139-147 (2005).

[11] P. Mpofu, J. Addai-Mensah, J. Ralston. Interfacial chemistry, particle interactions and improved dewatering behaviour of bentonite clay dispersions. International Journal of Mineral Processing, 75; 155-171 (2005).

[12] H. H. Murray, Overview - clay mineral applications, Appl. Clay Sci. 5; 379-395 (1991).

[13] H. H. Murray, Applied Clay Mineralogy: Occurrences, Processing and Application of Kaolins, Bentonites, Palygorskite-Sepiolite, and Common Clays. Elsevier B. $\mathrm{V}, 2006$.

[14] M. I. Attia, O. K. Alduaij1, L. Khezami, Assessment of Nickel(II) Removal from Aqueous Solution Using Saudi Bentonite. SYLWAN., 159(1)], 146-166 (2014).

[15] S. S. Al-Shahrani. Treatment of wastewater contaminated with cobalt using Saudi activated bentonite. Alexandria Engineering Journal, 53; 205-211 (2014).

[16] M. Monier, D. M. Ayadb, Y. Wei and A. A. Sarhanb. Adsorption of $\mathrm{Cu}(\mathrm{II}), \mathrm{Co}(\mathrm{II})$, and $\mathrm{Ni}(\mathrm{II})$ ions by modified magnetic chitosan chelating resin. Journal of Hazardous Materials, 177; 962-970 (2010).

[17] S. Rengaraj, K. H. Yeon, S. Y. Kang, J. U. Lee, K.W. Kim, S. H. Moon. Studies on adsorptive removal of $\mathrm{Co}(\mathrm{II}), \mathrm{Cr}(\mathrm{III})$ and $\mathrm{Ni}$ (II) by IRN77 cation-exchange resin. J Hazard Mater B92:185-198 (2002).

[18] M. W. Yang, R. L. Boles, T. P. Mawhinne. Determination of phosphorus in fertilizers by inductively coupled plasma atomic emission spectrometry. JAOAC Int., 85(6): 1241-1246 (2002).

[19] B. C. Lippens, J. H. De Boer. Pore systems in catalysts V. The t-method, J. Catalysis, 4; 319-323, 1965.

[20] N. Kannan, M. M. Sundaram, Kinetics and mechanism of removal of methylene blue by adsorption on various carbons - A comparative study, Dyes Pigments 51; 25 40 (2001).

[21] Y. S. Ho, G. McKay, Kinetic models for the sorption of dye from aqueous solution by wood, Process Saf. Environ. Protect. 76; 183-191 (1998).

[22] L. Khezami and R. Capart. Removal of chromium(VI) from aqueous solution by activated carbons: Kinetic and equilibrium studies. Journal of Hazardous Materials B123; 223-231 (2005). 
[23] S. J. Allen, G. Mckay, K. Khader. Intraparticle diffusion of a basic dye during adsorption onto sphagnum peat. $J$. Environ. Pollut. 50 39-50 (1989).

[24] K. P. Yadava, B. S. Tyagi, K. K. Panday, V. N. Singh, Fly ash for the treatment of Cd(II) rich effluents, Environ. Technol. Lett. 8; 225-234 (1987).

[25] D. J. L. Guerra, I. Mello, R. Resende, R. Silva. Application as absorbents of natural and functionalized Brazilian bentonite in $\mathrm{Pb}^{+2}$ adsorption: Equilibrium, kinetic, $\mathrm{pH}$ and thermodynamic effects. Water Resources and Industry 4 ; 32-50 (2013).

[26] J. A. Hefne, W. K. Mekhemer, N. M. Alandis, O. A. Aldayel, T. Alajyan. Removal of Silver(I) from Aqueous Solutions by Natural Bentonite. JKAU: Sci., 22 (1); 155-176 (2010).

[27] D. Shu-li, S. Yu-zhuang, Y. Cui-na, X. Bo-hui, Removal of copper from aqueous solutions by bentonite and the factors affecting it, J. Min. Sci. Technol. 19, 0489-0492 (2009).

[28] M. Onal, Y. Sarikaya, T. Alemdaroglu and I. Bozdogan. The Effect of Acid Activation on Some Physicochemical Properties of a Bentonite. Turk J Chem 26; 409-416 (2002).

[29] I. C. Bourg, G. Sposito and A. C. M. Bourg. Modeling cation diffusion in compacted water-saturated sodium bentonite at low ionic strength. Environ. Sci. Technol. 41; 8118-8122 (2007).

[30] S. Goldberg. Competitive Adsorption of Arsenate and Arsenite on Oxides and Clay Minerals. Soil Sci. Soc. Am. J. 66: 413-421 (2002).

[31] I. Dékány and L. G. Nagy. Immersional Wetting and Adsorption Displacement on Hydrophilic/hydrophobic Surfaces, J. Coll. Interface Sci., 147; 119-128 (1991).

[32] L. S. G. Galindo, A. F. de A. Neto, M. G. C. da Silva, M. G. A. Vieira. Removal of Cadmium (II) and Lead (II) Ions from Aqueous Phase on Sodic Bentonite. Materials Research. 16(2); 515-527 (2013).

[33] Ö. Yavuz, Y. Altunkaynak, F.Guzel. Removal of copper, nickel, cobalt and manganese from aqueous solution by kaolinite. Watet Res, 37; 948-952 (2003).

[34] T. N Webber, R. K. Chakravarti : Pore and Solid Diffusion Models for fixed bed absorbers. J. Am. Inst. Chem. Eng., 20; 228- 238 (1974).

[35] Y. S. Ho, C. T. Huang, H. W. Huang, Equilibrium sorption isotherm for metal ions on tree fern, Process. Biochem. 37; 1421-1430 (2002).

[36] M. J. Angove, B. B. Johnson and J. D. Wells. The influence of temperature on the adsorption of cadmium (II) and cobalt(II) on kaolinite. Journal of Colloid and Interface Science 204, 93-103 (1998).
[37] Z. Melichová and L. Hromada. Adsorption of $\mathrm{Pb}^{+2}$ and $\mathrm{Cu}^{+2}$ ions from aqueous solution by natural bentonite. Pol. J. Environ. Stud., 22 (2); 457-464 (2013).

[38] A. Wongkoblap, Y. Ngernyen, S. Budsaereechai, C. Atiwat. Heavy Metal Removal from Aqueous Solution by using Bentonite Clay and Activated Carbon: In: Chemeca 2013: Challenging Tomorrow. Barton, ACT: Engineers Australia,: 689-694. 2013 (Conference Paper).

[39] N. Chiron, R. Guilet and E. Deydier. Adsorption of $\mathrm{Cu}$ (II) and $\mathrm{Pb}$ (II) onto A Grafted Silica: Isotherms and Kinetic Models, Water Res., 37; 3079-3086 (2003).

[40] R. Donat, A. Akdogan, E. Erdem, H. Cetisli. Thermodynamics of $\mathrm{Pb}^{2+}$ and $\mathrm{Ni}^{2+}$ adsorption onto natural bentonite from aqueous solutions. Journal of Colloid and Interface Science 286; 43-52 (2005).

[41] Z. Q. Guo, Y. Li, S.W. Zhang, H. H. Niu, Z. S. Chen and J. Z. Xu. Enhanced sorption of radiocobalt from water by $\mathrm{Bi}(\mathrm{III})$ modified montmorillonite: A novel adsorbent. J Hazard Mater, 192; 168-175 (2011).

[42] A. A El-Bindary, A. Z. El-Sonbati, A. A. Al-Sarawy, K. S. Mohamed and M. A. Farid. Removal of hazardous azopyrazole dye from an aqueous solution using rice straw as a waste adsorbent: Kinetic, equilibrium and thermodynamic studies. Spectrochimica Acta, Part A: Molecular and Biomolecular Spectroscopy, 136; 1842 1849 (2015).

[43] H. Zheng, D. Liua, Y. Zheng, S. Liang and Z. Liua. Sorption isotherm and kinetic modeling of aniline on Crbentonite. Journal of Hazardous Materials 167; 141147 (2009).

[44] Z. Liu and S. Zhou. Adsorption of copper and nickel on Na-bentonite. Process Safety and Environmental Protection, 88; 62-66 (2010).

[45] K. G. Bhattacharyya and S. Sen Gupta, Adsorption of a few heavy metals on natural and modified kaolinite and montmorillonite: a review, Advances in Colloid and Interface Science, 140 (2); 114-131 (2008).

[46] D. Doulia, C. Leodopoulos, K. Gimouhopoulos, F. Rigas. Adsorption of humic acid on acid-activated Greek bentonite. Journal of Colloid and Interface Science, 340; 131-141 (2009).

[47] A. Zendelska, M. Golomeova, K. Blažev, B. Boev, B. Krstev, B. Golomeov, A. Krstev. Kinetic studies of manganese removal from aqueous solution by adsorption on natural zeolite. Macedonian Journal of Chemistry and Chemical Engineering, 34 (1); 213-220 (2015).

[48] N. B. Milosavljevic, M. D. Ristic, A. A. Peric-Grujic, J. M. Filipovic, S. B. `Strbac, Z. L. Rakocevic, M. T. K. Krusic. Removal of $\mathrm{Cu}^{2+}$ ions using hydrogels of chitosan, itaconic and methacrylic acid:FTIR, SEM/EDX, AFM, kinetic and equilibrium study. Colloids and Surfaces A: Physicochem. Eng. Aspects, 388; 59-69 (2011). 